$\mathrm{H}_{2} \mathrm{O}-\mathrm{CO}-\mathrm{CO}_{2}$ 系における炭素鋼，低合金鋼の 応力腐食割れについて*

\author{
小若 正 倫** 永 田 三 郎**
}

\title{
Some Aspects of Stress Corrosion Cracking of Mild and Low Alloy Steels in $\mathrm{H}_{2} \mathrm{O}-\mathrm{CO}-\mathrm{CO}_{2}$ Systems
}

\author{
Masamichi Kowaka† and Saburo Nagatat \\ † Central Research Laboratories, Sumitomo Metal Industries, Ltd. \\ 1-3, Nishinagasu-hondori, Amagasaki-shi, Hyogo-ken, Japan
}

\begin{abstract}
Effects of gas composition, temperature and alloying elements on stress corrosion cracking of mild and low alloy steels in $\mathrm{H}_{2} \mathrm{O}-\mathrm{CO}-\mathrm{CO}_{2}$ system were studied. Stress corrosion tests were carried out in $\mathrm{H}_{2} \mathrm{O}-\mathrm{CO}-\mathrm{CO}_{2}$ mixtures by using U-bend specimens. The test results were as follows. (1) Mild and low alloy steels suffered from transgranular stress corrosion cracking in $\mathrm{H}_{2} \mathrm{O}-\mathrm{CO}-\mathrm{CO}_{2}$ mixtures of vast ranges of $\mathrm{CO} / \mathrm{CO}_{2}$ ratio. (2) No stress corrosion cracking of mild steel was found in pure $\mathrm{CO}$ or $\mathrm{CO}_{2}$ gases with water, respectively. But stress corrosion cracking occurred when pure grade $\mathrm{CO}$ contained small amount of air $\left(0.03 \% \mathrm{CO}_{2}\right)$. (3) Oxygen in $\mathrm{H}_{2} \mathrm{O}-\mathrm{CO}-\mathrm{CO}_{2}$ mixture promoted the susceptibility to stress corrosion cracking of mild steel in liquid phase. $\mathrm{H}_{2} \mathrm{~S}$ in water showed the inhibiting effect. (4) Stress corrosion cracking occurred at testing temperatures of 20,40 , and $70^{\circ} \mathrm{C}$, but its susceptibility decreased over $100^{\circ} \mathrm{C}$ at which general corrosion was promoted. (5) Small amount of alloying elements in the steels, i. e., C, Mn, $\mathrm{Si}, \mathrm{Cr}, \mathrm{Mo}, \mathrm{Cu} \mathrm{W}, \mathrm{V}, \mathrm{Ti}, \mathrm{Nb}$ and $\mathrm{Al}$, had no prominent effect to stress corrosion cracking. But steels containing chromium more than $9 \%$ did not suffer from stress corrosion cracking. (6) This type of cracking was called stress corrosion cracking (anodic dissolution, not hydrogen embrittlement) because of the availability of cathodic protection. (7) Treatments to relieve residual stress in steels or application of steels containing chromium more than $9 \%$ may be used to prevent stress corrosion cracking.
\end{abstract}

\section{1 緒 专}

炭素鋼が貫粒型の応力腐食割れを起こすことは非常に 珍しく, Buchholtz らによりシアンを含む環境て起こる ことが示されているにすぎない1)。数年前著者らにより $\mathrm{H}_{2} \mathrm{O}-\mathrm{CO}-\mathrm{CO}_{2}$ 系で炭素鋼, 低合金鋼が貫粒割れを起こ すこと,ならびにこの系で割れに陰極防食が可能であ ることから陽極溶解型の応力腐食割れであることが報告

* 昭和 46 年 8 月 23 日第 18 回腐食防食討論会 (北海道)におい て発表

** 住友金属工業株式会社中央技術研究所（尼崎市西長洲本通 1 丁目 3 番地）
された ${ }^{2)}$ 。その後二酸化炭素含有量の高い同様な系で割 れが起こることが Brown らにより示されている゙3。

さらに最近 $\mathrm{CO}-\mathrm{CO}_{2}$ 系混合ガス容器が破壊し4), 対策 委員会（伊藤伍郎主査）が発足して著者らも参加し種々 検討されている5)。

その他直接, 間接に $\mathrm{H}_{2} \mathrm{O}-\mathrm{CO}-\mathrm{CO}_{2}$ 系で応力磨食割 れと判断される事故例をいくつか経験 はてており, 実験室 的に検討を進めてきた。

ここでは $\mathrm{H}_{2} \mathrm{O}-\mathrm{CO}-\mathrm{CO}_{2}$ 系における応力腐食割れ事故 例ならびに割れに及ぼす環境側因子 (ガス組成, 温度) および材料側因子（合金元素）について検討した結果を 


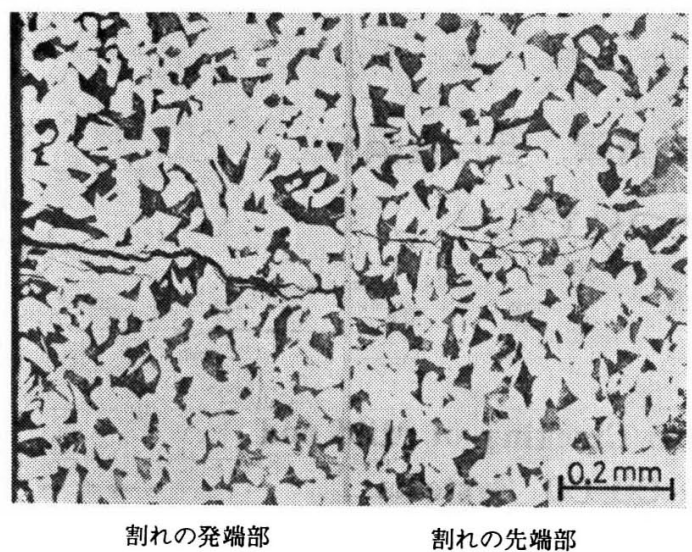

図 1 某化学プラントで発生した炭素鋼の割れ

報告する。

\section{$2 \mathrm{H}_{2} \mathrm{O}-\mathrm{CO}-\mathrm{CO}_{2}$ 系での応力屚食割れの特徽}

調査した結果によると $\mathrm{H}_{2} \mathrm{O}-\mathrm{CO}-\mathrm{CO}_{2}$ 系での応力腐食 割れと判断される場合の特徽として

1）溶接部や，拡管部などの残留応力のある場所，あ るいは熱応力などにより引張応力の存在する個所に割れ が発生する。

2）割れは炭素鋼っおよび低合金鋼に発生する。
表 1 割れ事故材付着物の X線解析結果

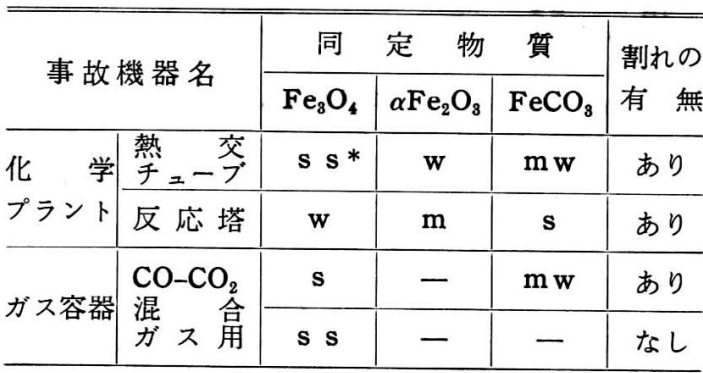

* s: 强い, w: 弱い, m: 中くらい(回折線の強き)

3) 明瞭な貫粒割れであり，一般に細い割れでかつ分 岐している。

4）全面腐食は軽微で, 黒色の腐食生成物が存在す る。X線解析の結果では酸化鉄ならびに炭酸鉄が検出さ れる。

5） 孔食が発生している場合があり，主としてパーラ イト部分が侵食されている。

6)温度は主として常温から $100^{\circ} \mathrm{C}$ まで範囲で起こ ることが多い。

7）時間的にはプラント運転開始後約半年から 1 年で 割れ事故が発生している。

表 2 供試材の化学組成と熱処理

\begin{tabular}{|c|c|c|c|c|c|c|c|c|}
\hline \multirow{2}{*}{ 鋼 } & \multicolumn{2}{|c|}{ 化 } & 姐 & \multicolumn{2}{|c|}{ (wt\%) } & \multirow{2}{*}{ 熱 } & \multirow{2}{*}{ 処 } & \multirow{2}{*}{ 理 } \\
\hline & C & $\mathrm{Si}$ & Mn & $\mathrm{Cr}$ & Mo & & & \\
\hline 炭 素 鋼 (STPG 42) & 0.22 & 0.30 & 0.55 & - & - & \multirow{3}{*}{\multicolumn{3}{|c|}{$\begin{array}{l}\text { 焼ならし } \\
\text { 油焼入れ, 焼もどし } \\
\text { 完全焼なまし }\end{array}$}} \\
\hline $1 \mathrm{Cr} \cdot \mathrm{Mo} \quad($ AISI 4130$)$ & 0.28 & 0.38 & 0.68 & 0.96 & 0.17 & & & \\
\hline $2^{1} / 4 \mathrm{Cr} \cdot 1 \mathrm{Mo}$ (STPA 24$)$ & 0.09 & 0.41 & 0.47 & 2.14 & 0.98 & & & \\
\hline $5 \mathrm{Cr} \cdot 1 / 2 \mathrm{Mo} \quad$ (STPA 25) & 0.10 & 0.37 & 0.45 & 4.57 & 0.50 & \multicolumn{3}{|c|}{ " } \\
\hline $9 \mathrm{Cr} \cdot 1 \mathrm{Mo} \quad$ (STPA 26) & 0.12 & 0.63 & 0.50 & 10.00 & 1.03 & \multicolumn{3}{|c|}{ " } \\
\hline $13 \mathrm{Cr} \quad$ (SUS 21) & 0.08 & 0.54 & 0.75 & 12.90 & - & \multicolumn{3}{|c|}{ 冷間加工 $\rightarrow$ 焼鈍 } \\
\hline $17 \mathrm{Cr} \quad$ (SUS 24) & 0.10 & 0.61 & 0.72 & 17.15 & - & \multicolumn{3}{|c|}{ " } \\
\hline $25 \mathrm{Cr}$ & 0.16 & 0.81 & 1.12 & 28.86 & - & \multicolumn{3}{|c|}{$"$} \\
\hline $18 \mathrm{Cr}-8 \mathrm{Ni} \quad$ (SUS 27) & 0.07 & 0.75 & 1.71 & 18.64 & $\begin{array}{l}\mathrm{Ni} \\
9.00\end{array}$ & \multicolumn{3}{|c|}{ 冷間加工 $\rightarrow$ 溶体化処理 } \\
\hline
\end{tabular}

表 3 実験に使用したガスの組成（vol\%）

\begin{tabular}{|c|c|c|c|c|c|c|c|}
\hline & & $\mathrm{Co}$ & $\mathrm{CO}_{2}$ & $\mathrm{O}_{2}$ & $\mathrm{~N}_{2}$ & $\mathrm{H}_{2} \mathrm{O}$ & $\mathrm{CH}_{4}$ \\
\hline \multirow{2}{*}{ 一般 ガ } & $\mathrm{CO}$ & 98.0 & 1.5 & 0.2 & 0.3 & - & - \\
\hline & $\mathrm{CO}_{2}$ & - & 99.7 & \multicolumn{2}{|c|}{ 空気 0.2} & - & - \\
\hline \multirow{2}{*}{ 高純度ガス } & $\mathrm{CO}$ & $>99.9$ & - & - & - & - & - \\
\hline & $\mathrm{CO}_{2}$ & - & $>99.99$ & 0.0005 & 0.0010 & 0.0005 & - \\
\hline \multirow{2}{*}{ 標 $\underset{\left(\mathrm{CO}-\mathrm{CO}_{2}\right)}{\text { 準 }}$} & a & 64.9 & 35.1 & - & - & - & - \\
\hline & b & 79.9 & 20.1 & - & - & - & - \\
\hline
\end{tabular}




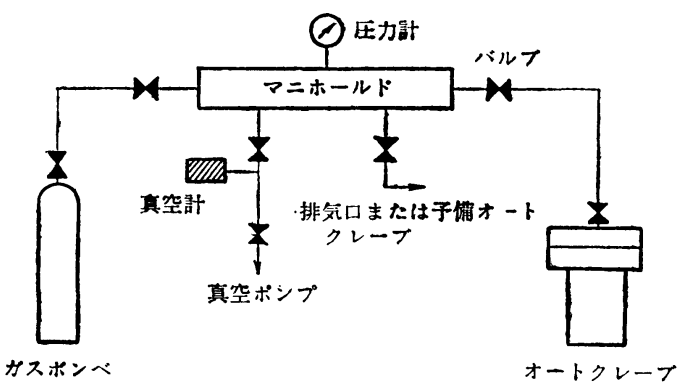

図 2 ガス充てん系の概略図

図 1 に化学プラントての割れの代表的な顕微鏡写真を 示す。さらに割れ事故発生材に付着していた腐食生成物 のX線解析結果を表 1 に示す。

\section{3 供試材と実酫方法}

使用した供試材の化学組成および熱処理条件を表 2 に 示す。このうち主として炭素鋼 (STPG 42) を使用した。 供試材より長さ $75 \mathrm{~mm} \times$ 幅 $10 \mathrm{~mm} \times$ 厚さ $2 \mathrm{~mm}$ の短冊 型試験片を切り出し, 最終的にエメリ一研摩紙 \#0(320 メッシュ) で研摩し，アセトンで脱脂した。

応力付加方法としては短時間で割れが発生するUベン ド法によった。曲げ試験機でU字型 (5R) とし，さらに 炭素鋼製のボルトおよびナットで脚部を $5 \mathrm{~mm}$ 締め付け て応力を付加した。またステンレス鋼試験片の場合は SUS 27 製のボルトおよびナットを用いた。

試験容器としてはSUS 32 製内容積 $2 l$ ならびに SUS 27 製内容積 $0.4 l$ のオートクレーブを使用した。試験片 はテフロン板にてオートクレーブ壁ならびにお互いに接 触しないように保持した。

試験は液相および気相で行なった。
試䮖に使用した水は蒸留水で，比抵抗は〜 $10^{6} \Omega \cdot \mathrm{cm}$ てある。

使用したガスは市販の一酸化炭素, 二酸化炭素 (以下 $\mathrm{CO}, \mathrm{CO}_{2}$ と記す) おょび高純度 $\mathrm{CO}, \mathrm{CO}_{2}$ ガスとそれら の混合ガスでその組成を表 3 に示す。

ガスの充てん方法は次の通りである。すなわち図 2 に 示すようにステンレス製マニーホールドを使用して，オ 一トクレーブならびに配管系をすべて油回転ポンプで真 空にし，さらに試験ガスを通して 3 回洗浄した後，試験 圧力までガスを充てんする。

試験は主として $40 \pm 1{ }^{\circ} \mathrm{C}$ で実施し，20，70，100なら びに $150^{\circ} \mathrm{C}$ にて温度の影響を検討した。

試験時間は 1 週間 (168時間) または 2 週間 (336時間) とした。

試験終了後Uベンド試験片の中央部約 $35 \mathrm{~mm}$ を縦に 切断し,中央断面部ならびに端部断面を樹脂に埋め込み, 研摩後金属顕微鏡 $(\times 400)$ て割れ判定を行なった。一部 については表面の腐食生成物をX線回析法にて調べた。

陰極防食の試験方法は前報”)と同様である。

\section{4 实路薄}

\section{4・1 カス相成の影要}

高純度の $\mathrm{CO}, \mathrm{CO}_{2}$ ガスならびに $\mathrm{CO}-\mathrm{CO}_{2}$ 系の標制ガ スを使用して試験した結果を事 4 に示す。

$\mathrm{CO}-\mathrm{CO}_{2}$ 系標軯ガスで $\mathrm{CO}, \mathrm{CO}_{2}$ の比が多少変わっ ても気相では応力腐食割れが発生し, 液相では材質によ って異なり，炭素鋼では割れないが，調質型の Cr ・ Mo

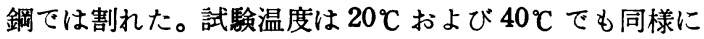
割れを生じた。

脱気しないで空気 $0.5 \sim 1 \mathrm{~kg} / \mathrm{cm}^{2}$ 入ったまま標準カ

表 $4 \mathrm{CO}-\mathrm{CO}_{2}$ 系麨準ガスならびに高純度ガスによる応力腐食割れ試験結果

(Uベンド法, 水量 $100 \mathrm{~m} l$ )

\begin{tabular}{|c|c|c|c|c|c|c|c|c|c|c|c|c|}
\hline & & & 標準カ & z $\left(\mathrm{CO}_{+}\right.$ & $\left.\mathrm{CO}_{2}\right)$ & 標华 & ガス+空 & & $\mathrm{CO}$ & $\mathrm{CO}+$ & 空気 & $\mathrm{CO}_{2}$ \\
\hline ガオ & 組成 & CO vol \% & 64.9 & 64.9 & 79.9 & 79.9 & 79.9 & 79.9 & $>99.9$ & $>99.9$ & $>99.9$ & - \\
\hline & & $\mathrm{CO}_{2}$ vol $\%$ & 35.1 & 35.1 & 20.1 & 20.1 & 20.1 & 20.1 & - & - & - & $>99.99$ \\
\hline & 空 & 气気, $\mathrm{kg} / \mathrm{cm}^{2}$ & - & - & - & 1 & 0.5 & 0.5 & - & 0.5 & (脱 $\begin{array}{r}0.5 \\
\mathrm{CO}_{2} \text { ) }\end{array}$ & - \\
\hline 全 & 王 力 & $\mathrm{kg} / \mathrm{cm}^{2}$ & 41 & 41 & 16 & 16 & 21 & 17 & 100 & 21 & 21 & 3 \\
\hline 試目 & 矣温度 & ${ }^{\circ} \mathrm{C}$ & 20 & 40 & 40 & 40 & 40 & 40 & 20 & 40 & 40 & $40 \rightarrow 20$ \\
\hline 試 & 免時間 & $\mathrm{hr}$ & 336 & 336 & 336 & 168 & 168 & 168 & 336 & 168 & 168 & 168 \\
\hline & & 炭 素 鋼 & $\mathrm{N}, \mathrm{N}$ & $\mathrm{N}, \mathrm{N}$ & $\mathrm{N}, \mathrm{N}$ & C & C & C & $\mathrm{N}, \mathrm{N}$ & C & $\mathrm{N}$ & $\mathrm{N}, \mathrm{N}$ \\
\hline 試* & 液相 & $1 \mathrm{C}_{\mathrm{r}} \cdot \mathrm{Mo}$ & C & $C, C$ & - & C & C & C & $\mathrm{N}, \mathrm{N}$ & - & $\mathbf{N}$ & $\mathrm{N}, \mathrm{N}$ \\
\hline 験 & & $2^{1} /{ }_{4} \mathrm{Cr} \cdot 1 \mathrm{Mo}$ & - & - & $\mathrm{N}, \mathrm{N}$ & C & C & $\mathrm{C}$ & - & C & $\mathrm{N}$ & - \\
\hline 結 & & 炭 素 鋼 & C & $\mathrm{C}, \mathrm{C}$ & $\mathrm{C}, \mathrm{C}$ & $\mathrm{N}$ & MC & $\mathrm{N}$ & $\mathrm{N}, \mathrm{N}$ & $\mathrm{N}$ & $\mathrm{N}$ & $\mathrm{N}, \mathrm{N}$ \\
\hline 果 & 気相 & $1 \mathrm{Cr} \cdot \mathrm{Mo}$ & $\mathrm{C}, \mathrm{C}$ & C, C & - & $\mathrm{N}$ & - & - & $\mathrm{N}, \mathrm{N}$ & - & - & $\mathrm{N}, \mathrm{N}$ \\
\hline & & $2^{1} / 4 \mathrm{Cr} \cdot 1 \mathrm{Mo}$ & - & - & $C, C$ & $\mathrm{~N}$ & MC & C & - & $\mathrm{N}$ & - & - \\
\hline
\end{tabular}

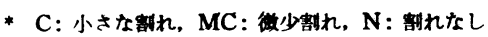


表 5 空気存在下での $\mathrm{H}_{2} \mathrm{O}-\mathrm{CO}-\mathrm{CO}_{2}$ 系での応力腐食割れ試験結果

(水量: $720 \mathrm{~m} l$, 供陚材：炭素䤡, $40^{\circ} \mathrm{C}$ で 186 時間試験)

\begin{tabular}{|c|c|c|c|c|c|c|c|c|c|}
\hline \multicolumn{2}{|c|}{ 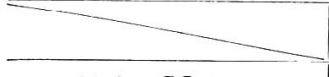 } & \multicolumn{5}{|c|}{$\mathrm{CO}+\mathrm{CO}_{2}$} & $\mathrm{CO}+\mathrm{CO}_{2}+\mathrm{H}_{2} \mathrm{~S}$ & \multirow{2}{*}{$\frac{\mathrm{CO}}{15}$} & \multirow{2}{*}{$\frac{\mathrm{CO}_{2}}{-}$} \\
\hline \multicolumn{2}{|c|}{ ガス組成, $\mathrm{CO} \mathrm{kg} / \mathrm{cm}^{2}$} & 6 & 8 & 12.5 & 12.5 & 21 & 12.5 & & \\
\hline \multirow{2}{*}{\multicolumn{2}{|c|}{$\begin{array}{r}\mathrm{CO}_{\mathrm{s}} \mathrm{kg} / \mathrm{cm}^{2} \\
\text { 空気 } \mathrm{kg} / \mathrm{cm}^{2}\end{array}$}} & 2.5 & 2.5 & 25 & 2.5 & 2.5 & 2.5 & $(0.23) * *$ & 2.5 \\
\hline & & 1 & 1 & 1 & 1 & 1 & 1 & 1 & 1 \\
\hline \multicolumn{2}{|c|}{ 全压力, $\quad \mathrm{kg} / \mathrm{cm}^{2}$} & 9.5 & 11.5 & 16 & 16 & 24.5 & 16 & 16 & 3.5 \\
\hline \multirow{4}{*}{ 試験 } & \multirow{4}{*}{ 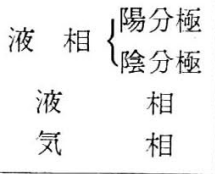 } & $\mathrm{N}$ & $\mathrm{N}$ & $\mathrm{C}$ & $\mathrm{C}$ & $\mathrm{L} \mathrm{C} * * *$ & $\mathrm{~N}$ & $\mathrm{C}$ & $\mathrm{N}^{* * *}$ \\
\hline & & $\mathrm{N}$ & $\mathrm{N}$ & $\mathrm{N}$ & $\mathrm{N}$ & $\mathrm{N}^{* * *}$ & $\mathrm{~N}$ & $\mathrm{~N}$ & $\mathrm{~N}^{* * *}$ \\
\hline & & $\mathrm{N}$ & $\mathrm{N}$ & $\mathrm{C}$ & $\mathrm{C}$ & $\mathrm{C}$ & $\mathrm{N}$ & $\mathrm{C}$ & $\mathrm{N}$ \\
\hline & & $\mathrm{N}$ & $\mathrm{N}$ & $\mathrm{N}$ & $\mathrm{C}$ & $\mathrm{MC}$ & $\mathrm{N}$ & $\mathrm{N}$ & $\mathrm{N}$ \\
\hline
\end{tabular}

* LC: 大きな割れ， C: 小さな割れ， MC: 微少割れ, N：割れなし

** $\mathrm{CO}$ 中に含有されている $\mathrm{CO}_{2}$ 量から計算

***陚験片間の電流偡 $0.15 \mathrm{~mA}$, 他は $1.5 \mathrm{~mA}$

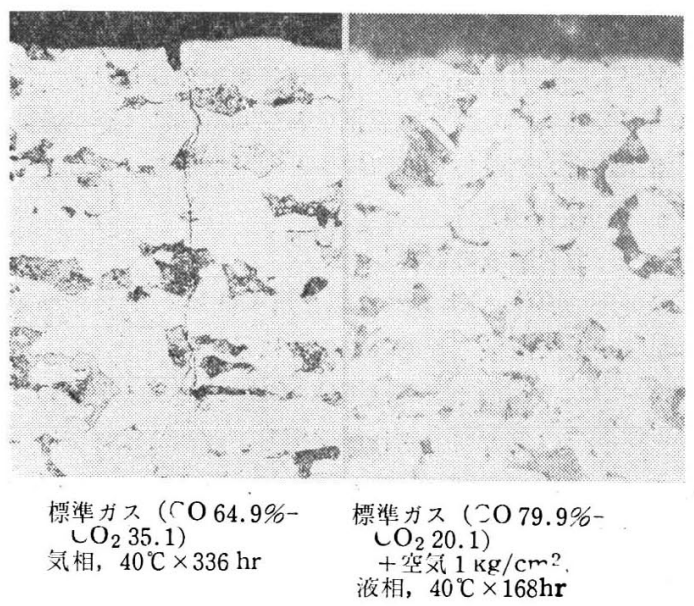

図 $3 \mathrm{H}_{2} \mathrm{O}-\mathrm{CO}-\mathrm{CO}_{2}$ 系での炭菜鋼の応力腐食割れ

スを充てんした場合には液相では割れ，気相では割れた

り，割れなかったり結果はばらつきを示した。

高純度 $\mathrm{CO}, \mathrm{CO}_{2}$ ガス単独では液相, 気相いずれにて る割れなかった。CO+空気では液相で割れたが，空気 に含有されている約 $0.03 \mathrm{vol} \%$ の $\mathrm{CO}_{2}$ の除去を目的と して $60 \% \mathrm{KOH}$ を通じて空気を允てんした $\mathrm{CO}+$ 空気系 こは割れが生じなかった。

表 5 には市販の $\mathrm{CO}, \mathrm{CO}_{2}$ ガスを使用して空気が共存 する状態で試験した結果を示す。この場合には $2.5 \mathrm{~kg} /$ $\mathrm{cm}^{2}$ の $\mathrm{CO}_{2}$ を充てんし, 種々の圧力で $\mathrm{CO}$ を充てんし た結果である。

$\mathrm{CO}$ の圧力が增し， $12.5 \mathrm{~kg} / \mathrm{cm}^{2}$ 以上になると応力腐 食割れが起こること, さらに気相中に比較して液相中の 方が割れやすいことを示す。

CO ガス単独でも割れを示したが，含有されている不 純分としての $\mathrm{CO}_{2}\left(0.23 \mathrm{~kg} / \mathrm{cm}^{2}\right)$ が共存しているため と考えられる。 $\mathrm{CO}_{2}$ ガス単独では空気が存在して为, 高
表 $6 \mathrm{H}_{2} \mathrm{O}-\mathrm{CO}-\mathrm{CO}_{2}$ 系の応力腐食割孔に及ぼす 試験温度の影響

$\left(\mathrm{CO} 12.5 \mathrm{~kg} / \mathrm{cm}^{2}-\mathrm{CO}_{2} 2.5 \mathrm{~kg} / \mathrm{cm}^{2}\right.$ 一筀気 $1 \mathrm{~kg} / \mathrm{cm}^{2}$, 水量 $700 \mathrm{~m} l, 168$ 時問, 炭素銅)

\begin{tabular}{|c|c|c|c|c|}
\hline $\begin{array}{c}\text { 試験温度 } \\
{ }^{\circ} \mathrm{C} \\
\end{array}$ & 液 相 & 陽分極**| & 陰分極**| & 気 相 \\
\hline 40 & $\mathrm{C}^{*}$ & $\mathrm{LC}$ & $\mathrm{N}$ & $\mathrm{C}$ \\
\hline 70 & $\mathrm{C}$ & $\mathrm{L} \mathrm{C}$ & $\mathrm{N}$ & $\mathrm{C}$ \\
\hline 100 & $\mathrm{~N}$ & $\mathrm{~N}$ & $\mathrm{~N}$ & $\mathrm{MC}$ \\
\hline 150 & $\mathrm{~N}$ & $\mathrm{~N}$ & $\mathrm{~N}$ & $\mathrm{MC}$ \\
\hline
\end{tabular}

* LC: 大き㓡れ, C: 小さな割れ, MC: 微少割れ， $\mathrm{N}$ : 割れなし ** 試験片間の電流量 $1.5 \mathrm{~mA}$

純度 $\mathrm{CO}_{2}$ の場合と同様割れなかった。

水に硫化水素を $395 \mathrm{ppm}$ 含有させた場合 $\mathrm{CO}-\mathrm{CO}_{2}$ 混 合ガスで応力腐食割狆が発生せず, 硫化水素は割れに対 してインヒビターとして働くことがわかった。

陽分極した試験片は応力腐食割れを起こしたが, 陰分 極した場合には全ての条件で割れなかった。

割れの代表的な顕微鏡写真を図 3 に示す。割れは炭素 鋼のフェライト，パーライトを貫通して抢り，典型的な 貫粒型である。空気が存在する場合には割れとともにパ ーライト部分が浸食されている場合があった。

\section{$4 \cdot 2$ 割れに及ぼす温度の影䍌}

前節で $40^{\circ} \mathrm{C}$ ならびに $20^{\circ} \mathrm{C}$ て割れが起こることを示し たがささらに高温の場合について検討した結果を表 6 に 示す。市販の $\mathrm{CO}, \mathrm{CO}_{2}$ ガスをそれぞれ $12.5 \mathrm{~kg} / \mathrm{cm}^{2}$, $2.5 \mathrm{~kg} / \mathrm{cm}^{2}$ を空気ありのままで充てんし(室温で), 試 験温度に保持した結果である。したがって試験温度では 高温ほど高圧力になっている。

液相中で $40^{\circ} \mathrm{C}, 70^{\circ} \mathrm{C}$ で割れ, $100^{\circ} \mathrm{C}$ 以上では割れな かった。また陽分極した場合にも同じ結果であり，陰分 極の場合には割れを生じなかった。

気相中では $40 \sim 150^{\circ} \mathrm{C}$ まですべて割れを示したが， 
表 7 腐食生成物の X線解析結果

（表 6 に示す液相または陽分極した試験片を使用）

\begin{tabular}{c|c|c|c|c}
\hline $\begin{array}{c}\text { 試験温度 } \\
{ }^{\circ} \mathrm{C}\end{array}$ & $\alpha \mathrm{Fe}$ & $\mathrm{Fe}_{3} \mathrm{O}_{4}$ & $\mathrm{FeCO}_{3}$ & 不明線 \\
\hline 40 & $\mathrm{~s} \mathrm{~s}$ & - & - & あり \\
70 & $\mathrm{~s} \mathrm{~s}$ & - & - & あり \\
100 & $\mathrm{~s} \mathrm{~s}$ & - & $\mathrm{m} \mathrm{s}$ & なし \\
150 & $\mathrm{~s}$ & $\mathrm{~s}$ & $\mathrm{~s}$ & なし \\
\hline
\end{tabular}

$\mathrm{s}:$ 強い, $\mathrm{m}:$ 中くらい

表 8 現用鋼の応力腐食割れ試験結果 $(336 \mathrm{hr})$

\begin{tabular}{|c|c|c|c|}
\hline & 標準ガス & $\begin{array}{l}\text { 標準ガ } \\
\text { +空 気 }\end{array}$ \\
\hline \multicolumn{2}{|c|}{ ガス組成 $\mathrm{CO}, \%$} & 64.9 & 79.9 \\
\hline & $\mathrm{CO}_{2}, \%$ & 35.1 & 20.1 \\
\hline & 空気, $\mathrm{kg} / \mathrm{cm}^{2}$ & - & 1 \\
\hline \multicolumn{2}{|c|}{ 全圧力 $\mathrm{kg} / \mathrm{cm}^{2}$} & 41 & 21 \\
\hline \multicolumn{2}{|c|}{ 試験片浸漬位置 } & 気 相 & 液 相 \\
\hline \multicolumn{2}{|c|}{ 試 験 温 度 ${ }^{\circ} \mathrm{C}$} & $20^{*}$ & 40 \\
\hline \multirow{8}{*}{$\begin{array}{l}\text { 割れ試 } \\
\text { 験結果 }\end{array}$} & 炭 素 鋼 & $\mathrm{C}$ & $\mathrm{L} \mathrm{C}$ \\
\hline & $2^{1} /{ }_{4} \mathrm{Cr} \cdot 1 \mathrm{Mo}$ & $\mathrm{C}$ & $\mathrm{LC}$ \\
\hline & $5 \mathrm{Cr} \cdot 0.5 \mathrm{Mo}$ & $\mathrm{N}$ & $\mathrm{C}$ \\
\hline & $9 \mathrm{Cr} \cdot 1 \mathrm{Mo}$ & $\mathrm{N}$ & $\mathrm{N}$ \\
\hline & $13 \mathrm{Cr}$ & $\mathrm{N}$ & $\mathrm{N}$ \\
\hline & $17 \mathrm{Cr}$ & $\mathrm{N}$ & $\mathrm{N}$ \\
\hline & $25 \mathrm{Cr}$ & $\mathrm{N}$ & $\mathrm{N}$ \\
\hline & $18 \mathrm{Cr} \cdot 8 \mathrm{Ni}$ & $\mathrm{N}$ & $\mathrm{N}$ \\
\hline
\end{tabular}

* $40^{\circ} \mathrm{C} \times 1 \mathrm{hr}$ 保持後試験

$100^{\circ} \mathrm{C}$ 以上では微少割れであった。温度が $100^{\circ} \mathrm{C}$ を越え ると全面腐食型となり, 黒色の厚い腐食生成物が存在し た。

表 7 に表面の窝食生成物のX線解析結果を示す。腐食 生成物は 40 打よび $70^{\circ} \mathrm{C}$ の場合には皮膜が薄く十分解析 ができなかった。 $100^{\circ} \mathrm{C}$ 以上の試験では炭酸鉄が検出さ れた。

\section{$4 \cdot 3$ 割れに及ぼす合金元素の影留}

表 2 に示した供試材の試験結果を表 8 に示す。標準ガ スを使用して気相で試験した結果では $5 \mathrm{Cr}-0.5 \mathrm{Mo}$ 鋼, $9 \mathrm{Cr}-1 \mathrm{Mo}$ 鋼ならびに $18 \mathrm{Cr}-8 \mathrm{Ni}$ ステンレス鋼は割れな かった。しかしながら空気が存在した状態で高純度標準 ガスを充てんして液相で試験した場合には $5 \mathrm{Cr}-0.5 \mathrm{Mo}$ 鋼は図 4 に示すように割れを生じた。

表 9 には種々の合金元素を添加した場合の結果を示 す。高周波炉で溶製し， $6 \mathrm{t}$ に圧延後短冊型試験片を切 り出し, 真空炉中で $900^{\circ} \mathrm{C} \times 30$ 分空冷の熱処理を施し た。割れ環境として厳しい条件である空気が共存する状

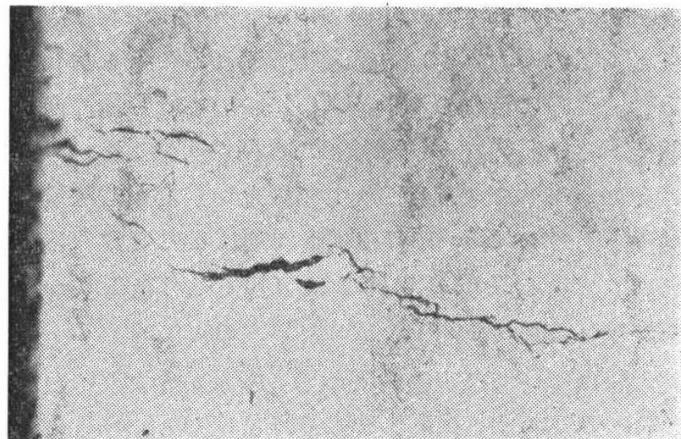

図 $45 \mathrm{Cr}-0.5 \mathrm{Mo}$ 鋼の応力腐食割れ

標準カス 空気 $1 \mathrm{~kg} / \mathrm{cm}^{2}$, 波相 $40^{\circ} \mathrm{C} \times 336 \mathrm{hr}$

表 $9 \mathrm{H}_{2} \mathrm{O}-\mathrm{CO}-\mathrm{CO}_{2}$ 系の応力腐食割れ試験結果

\begin{tabular}{|c|c|c|c|c|}
\hline 代 & 試 & 材* & \multicolumn{2}{|c|}{ 応力腐食割れ試験結果 } \\
\hline \multicolumn{2}{|c|}{$\begin{array}{c}\text { 変化元素とその量 } \\
\text { (wt \%) }\end{array}$} & 組 織 & $1^{* *}$ & $2^{* * *}$ \\
\hline \multirow[t]{3}{*}{$\mathrm{C}$} & 0.20 & $F+P$ & $\mathrm{~N}$ & L C \\
\hline & 0.30 & $F+P$ & $\mathrm{MC}$ & \\
\hline & 0.41 & $F+P$ & $\mathrm{MC}$ & \\
\hline $\mathrm{Si}$ & 0.96 & $F+P$ & $\mathrm{C}$ & \\
\hline $\mathrm{Mn}$ & 1.15 & $F+P$ & $\mathrm{C}$ & \\
\hline $\mathrm{Cu}$ & 0.39 & $F+P$ & $\mathrm{C}$ & \\
\hline \multirow[t]{2}{*}{$\mathrm{Cr}$} & 0.97 & $F+P$ & $\mathrm{C}$ & \\
\hline & 1.74 & $B+P$ & $\mathrm{C}$ & \\
\hline Mo & 0.33 & B & $\mathrm{MC}$ & \\
\hline W & 0.47 & $F+P$ & $\mathrm{~N}$ & L C \\
\hline $\mathrm{V}$ & 0.08 & $F+P$ & $\mathrm{~N}$ & L C \\
\hline $\mathrm{Ti}$ & 0.26 & $F+P$ & $\mathrm{~N}$ & L C \\
\hline $\mathrm{Nb}$ & 0.19 & $F+P$ & $\mathrm{~N}$ & L C \\
\hline $\mathrm{Al}$ & 0.31 & $F+P$ & $\mathrm{MC}$ & \\
\hline 炭素鋼 & STPG 42 & $F+P$ & $\mathrm{C}$ & L C \\
\hline
\end{tabular}

* 基本系 $0.30 \mathrm{C}-0.25 \mathrm{Si}-0.70 \mathrm{Mn}-0.015 \mathrm{P}-0.015 \mathrm{~S}$ $900^{\circ} \mathrm{C} \times 30 \mathrm{~min}$ A.C., $\mathrm{F}:$ フェライト, P: ポーライト, B: た ーナイト

** 標準ガス $\left(79.9 \% \mathrm{CO}, 20.1 \% \mathrm{CO}_{2}\right), 15 \mathrm{~kg} / \mathrm{cm}^{2}$, 気相, $40^{\circ} \mathrm{C}$ $\times 336 \mathrm{hr}$.

*** 標準ガス $\left(79.9 \% \mathrm{CO}, 20.1 \% \mathrm{CO}_{2}\right) 20 \mathrm{~kg} / \mathrm{cm}^{2}+$ 空気 $1 \mathrm{~kg} / \mathrm{cm}^{2}$ 液相, $40^{\circ} \mathrm{C} \times 336 \mathrm{hr}$.

態ではすべて割れ，この程度の添加量では特に有効な元 素は見いだせなかった。

5 考察

以上 $\mathrm{H}_{2} \mathrm{O}-\mathrm{CO}-\mathrm{CO}_{2}$ 系の応力腐食割れについての諸要 因の影響について報告した。

$\mathrm{H}_{2} \mathrm{O}-\mathrm{CO}-\mathrm{CO}_{2}$ 系で応力腐食割れを起こすことはすで に報告したと打りである ${ }^{2)}$ 。今回報告した実験は $\mathrm{CO}_{2}$ に 比較して CO 含有量の多い組成についてである。CO 1 $\%, \mathrm{CO}_{2} 17 \%, \mathrm{~N}_{2} 82 \%$, 全圧力 $100 \mathrm{~kg} / \mathrm{cm}^{2} \mathrm{G}$ の環境 
でむ水分が存在すれは $\mathrm{Mn}$ 鋼， $\mathrm{Cr}-\mathrm{Mo}$ 鋼が割れ，また ほとんどの $\mathrm{Co}, \mathrm{CO}_{2}$ の組合せで割れることを示してい る5)。さらに微量の $\mathrm{CO}, \mathrm{CO}_{2}$ については今後の検討課 題である。高純度 $\mathrm{CO}$ 単独で恃今回の実験です，CO 委 員会の報告らでも割れが生じていない。しかし微量の不 純物としての $\mathrm{CO}_{2}$ が存在すれば割れることは報告した と打りである。 $\mathrm{CO}_{2}$ 単独では（脱気の有無にかかわら ず）割れなかった。

水分については実験結果からも明らかなように，水を オートクレーブに入れ，実験温度に保持した場合に気相 でも割れることから，実験温度での飽和水蒸気で良いと 考えられる。ただし気相中に置いた試験片上での水分の 状態がどうなっているのか明らかではないが，脱気した 条件で割れを示した場合には試験片全体が灰色に最って いること，さらに実験中の温度変動もあることから結露 し，薄い水膜として存在していたものと考えられる。な お脱気せず空気が存在する条件では液相に比較して気相 では割れにくい。表面状態は眖気ありの場合と異なっ て, $40^{\circ} \mathrm{C}$ では金属光沢を示し，局部的に点状発錆を示して おり，脱気した場合と異なった状況を示した。この表面 状態の相違がどのような原因によるのか明らかでない。

脱気の有無,すなわち油回転ポンプで脱気し高純度の 標準ガスを充てんした場合と空気の存在のまま標準ガス および $\mathrm{CO}, \mathrm{CO}_{2}$ ガスを充てんした場合では割れ感受性 が異なり，炭素鋼は液相中では脱気した場合は割れない が，脱気しない場合には短時間で割れる。この相違は空 気中の酸素の作用と考えられ，酸素が共存すれば割れ感 受性が増大することを示している。 $\mathrm{H}_{2} \mathrm{O}-\mathrm{CO}-\mathrm{CO}_{2}$ 系の 割れにおける酸素の役割についてはさらに検討を要す る。なお窒素は共存しても影響しないら)。

低炭素鋼が応力腐食割れを生ずる環境については数多 く報告されているが6)，主として粒界割れであって，硝 酸塩水溶液, アルカリ水溶液, 石炭乾燥ガスなどがよく 知られている。貫粒型の例は少なく, $\mathrm{HCN}$ 水溶液 ${ }^{11}$, $\mathrm{H}_{2} \mathrm{~S}$ 水溶液7)，G.-V. 溶液8)にすぎない。この内 $\mathrm{H}_{2} \mathrm{~S}$ 溶 液は水素脆化に基つく割れと結論されている。

$\mathrm{H}_{2} \mathrm{O}-\mathrm{CO}-\mathrm{CO}_{2}$ 系での割れに対しては陰極防食が 可能 であることから陽極溶解型の応力腐食割れであると結論 した。またこの事実と $\mathrm{H}_{2} \mathrm{~S}$ はこの系での割れ防止に効 果があることと関連していると考えられる。さらに $\mathrm{CN}^{-}$ イオンについて分析したところ存在が確認されなかっ た

$\mathrm{H}_{2} \mathrm{O}-\mathrm{CO}-\mathrm{CO}_{2}$ 系では $\mathrm{CO}_{2}$ 溶解による炭酸イオンの存 在は当然考えられるが，その上キ酸が生成されているこ とが確認されており ${ }^{10)}$ ，これらの酸の影響孔考えられる。 CO はギ酸, 塩酸などの酸に対してその全面腐食を低減 する作用を有する。たとえばアルゴンで眖気した 0.02
規定の塩酸中に 1 気压のアルゴンならびにCO を封入し て炭素鋼を $35^{\circ} \mathrm{C} \times 72$ 時間浸漬した結果, アルゴン封入で 腐食減量 $5 \mathrm{mg} / \mathrm{cm}^{2}$ に対し, $\mathrm{CO}$ 封入の場合には $1 \mathrm{mg} /$ $\mathrm{cm}^{2}$ になる。このように酸による腐食に対して，CO が 吸着してインヒビターとして働くことは明らかであり， 電位が貴となって，局部的に陽極溶解が進むものと解釈 される ${ }^{3)}$ が，さらに電気化学的な検討を要する。

割れに対する合金元素の影響については低合金鋼の範 团では多少合金元素を添加しても，割れ感受性の改善は むずかしいようである。Cr 量が $9 \%$ 以上になれば割れ なかったが，試験時間 2 週間という限定されたものでさ らに長時間の試験が必要である。したがって材料側から の割れ防止対策としては 1 ) 溶接部では応力除去焼鈍の 実施，さらに苛酷な嫄境では 2 ) ステンレス鋼の探用が 現在のところ最も有効である。経験した事故プラントで はこれらの対策を実施している。

\section{6 結 論}

$\mathrm{H}_{2} \mathrm{O}-\mathrm{CO}-\mathrm{CO}_{2}$ 系での応力腐食割れについて種々の要 因について検討し，次の結果を得た。

1) $\mathrm{H}_{2} \mathrm{O}-\mathrm{CO}-\mathrm{CO}_{2}$ の3 者が共存すれば炭素鋼, 低合金 鋼は貫粒型の応力腐食割れを起こす。高純度の $\mathrm{CO}, \mathrm{CO}_{2}$ ガス単独では割れない。しかし少量の $\mathrm{CO}_{2}$ を含む $\mathrm{CO}$ ガ ス中では割れる。

2）酸素が存在すれば流相中での割れ感受性を增大す る。

3）水中に硫化水素を $400 \mathrm{ppm}$ 程度含有させれば 割 れ感受性が低下し、インヒビターの役割をはたす。

4) 温度が $20 \sim 70^{\circ} \mathrm{C}$ の間では割れやすく, $100^{\circ} \mathrm{C}$ 以上 になると割れにくくなる。その場合には全面腐食型とな る。

5) 合金元素として, C, Si, Mn, Cu, Cr, Mo, W, $\mathrm{V} ， \mathrm{Ti}, \mathrm{Nb}, \mathrm{Al}$ の影響を検討したが，少量ては有効な 元素は見いだせなかった。 $\mathrm{Cr}$ 量を $9 \%$ 以上含有する 9 $\mathrm{Cr}-1 \mathrm{Mo}$ 鋼, $13 \mathrm{Cr}$ 鋼, $18 \mathrm{Cr}$ 鋼, $25 \mathrm{Cr}$ 鋼および $18 \mathrm{Cr}-$ $8 \mathrm{Ni}$ 鋼は割れを生じなかった。

6）陰極防食が可能なことから陽極溶解型の応力腐食 割れと考えられ，CO は腐食に対してインヒビターとし て働き，割れに関与するものと考号られる。

7）対策としては高 $\mathrm{Cr}$ 合金鋼を使用するか, 残留応 力除去焼鈍を行なうかにより応力腐食割れを防止するこ とができ。 （昭和46年11月 12 日受理）

\section{至 考 献}

1) H. Buchholtz \& R. Pursh: Stahl u. Eisen, 62, 21 (1942).

2) M. Kowaka \& S. Nagata: Corrosion, 24, 427 (1968)

3) A. Brown, J. T. Harrison \& R. W. Wilkins: 
Corr. Sci., 10, 547 (1970).

4）高圧ガス保安協会報, No. 73， 8 (1970).

5） $\mathrm{CO}$ 委員会：高圧ガス保安協会報, No. 84, 9 (1970).

6）たとえば R. N. Parkins：“Proceedings of Conference Fundamental Aspects of Stress Corrosion Cracking" p. 361, NACE (1969).
7) H. L. Logan \& H. T. Yolken: “Proceedings of the Second International Congress on Metallic Corrosion" p. 109, NACE (1966).

8 ) 内藤, 橋本, 木原：石油学会誌, 14, 672(1971).

9) Private Communication.

10)栂野, 阪東：第 4 回 CO 委員会提出資料 (1971. 4. 15). 